\section{Outward Mobility of Saudi Students: An Overview}

\section{Manail Anis Ahmed}

Manail Anis Ahmed is an international higher education management professional with experience working with institutions in the United States, South Asia, and the Middle East. She is the Head of Global Resource Development for Habib University, a private liberal arts university in Karachi, Pakistan. E-mail: manailahmed@gmail.com.

ince the earliest group of six Saudi students was sent by King Abdul Aziz to acquire higher education in Cairo in I927, Saudi Arabia has come very far in terms of outward student mobility at the university level. The country's first university was not established until I957, so for many decades prior to this, and indeed until the current time in certain fields, Saudi students have had no choice but to head overseas for a university education. Both the government and private citizens have been conscious of this need and have committed substantial sums of money-and corresponding amounts of energy and effort-to educating university students overseas.

\section{The Saudi Scholarship Program}

The most noteworthy aspect of Saudi university students' outward mobility has been the custodian of the Two Holy Mosques Scholarship Program. This has been a multi-million dollar undertaking - and arguably the largest national scholarship program worldwide. Launched by the late King Abdullah in 2005, this program formalized the longstanding and already active outward flow of Saudi students to universities worldwide. It aimed to send 50,000 Saudi men and women to higher education institutions overseas. Renewed with the subsequent five-year Saudi development plan in 20Io, it has to date educated a far greater number of citizens than was earlier envisioned.

The most recent time frame for which the Saudi government has made numbers publicly available is the Saudi statistical yearbook from the Hijri year I433-I434, corresponding to the academic year 20I2-2013. These include statistics for general demographics, health, social services, transportation, communications, water, energy, the labor market, and so on. A substantial section deals with education, within which higher education both inside and outside the country is addressed. In total, for the academic year 20I2-20I3, almost 200,000 Saudi students were overseas to acquire higher education (199,285 to be exact). Of these, a staggering 165,908 were funded by government scholarships, with the rest being privately funded.

\section{Saudi Female Students Abroad}

The yearbook provides statistics for both males and females. One of the most remarkable things about the breakdown of students by gender is the substantial proportion of Saudi students studying abroad who are female (I50,I09 males and 49,I76 females-roughly a 3:I ratio). It is a testament to the Kingdom's commitment to education for women that the program generously sponsors an accompanying male relative for every Saudi female awarded a scholarship. The Saudi cultural bureaus and missions in the host countries provide orientation and assistance to these citizens at every stage of the educational process. This has been a creative way to ensure that Saudi females can receive the same world-class education as their male counterparts, without ruffling religious feathers or upending the status quo. The cultural and social expectations of Saudi females are thus upheld, while they avail themselves of world-class educational opportunities.

\section{Breakdown by Destination Country}

Saudi students travel to more familiar systems such as the United States, Britain, Canada, and Australia—but also to European countries, such as the Netherlands, Germany, and Italy, and indeed many countries in Asia, such as China, India, Malaysia, Singapore, South Korea, and Japan. In addition, there is a substantial number of Saudi students studying in other Arab countries, such as Egypt, Lebanon, and Jordan. The overwhelming majority of students predictably head to English-speaking countries, with the United States being the single host country with the largest influx of Saudi students at any given time, with Britain following close behind.

\section{Breakdown by Field of Study}

Writing in 2009, the Undersecretary for Scholarships at the then Ministry of Higher Education, Abdullah bin Abdul Aziz Al-Mousa, reflected on the purpose of Saudi scholarships to foreign universities being to "train and develop Saudi human resources with the aim of enabling them to become competitive in the labor market and scientific research, and provide key support to public and private Saudi universities." This has been ensured, according to him, by highlighting fields critical for the country's economic development, and encouraging Saudi students to undertake programs of study within them.

Consequently, the Saudi government encourages scholarships in medical/health and engineering sciences, followed by information/communication, computer science, and basic sciences. Business studies-in subjects such as accounting, management, finance, e-commerce, insurance, marketing, and regulatory law-are also encouraged, however; this field is favored more by self-funded students 
coming from entrepreneurial and industrial backgrounds. Therefore, when viewed by subject breakdown, the largest single field of study turns out to be business and management-with engineering and related sciences following close behind. The third predominant field of study is medical and health-related sciences, the fourth being informatics. Quite surprisingly, over 7,000 Saudi students were enrolled in humanities subjects in 20122013 , another 3,644 in the social sciences, and I,496 in the arts. However, a deplorably low number undertook teacher training (a mere 1,899 ), which would be a contributing factor to why the overall quality of teaching in the Saudi state educational system is slow to improve. On the other hand, though low, enrollments in environmental protection studies, agriculture, forestry, fish farming, productivity and manufacturing industries studies, science education, and press and media studies, indicate important steps in the right direction for the Kingdom.

\section{The most noteworthy aspect of Saudi university students' outward mobility has been the custodian of the Two Holy Mosques Scholarship Program.}

\section{Breakdown by ACADEmic LeVel}

Within higher education, Saudi students abroad are clustered for the most part at the bachelor's degree level 160 percent). Some 24 percent are studying for their master's degrees, and another 5 percent toward their doctorate. Of the total number of scholarship recipients, the government sponsors a substantial proportion (8 percent) for fellowships and other advanced professional training. The remaining take up studies for associate degrees, intermediate and higher diplomas, and other training programs.

\section{Implications of OUtward Student Mobility}

The social and cultural impact of this massive student movement outward is quite clearly evident to any resident of the Kingdom. Briefly, the country has changed and is changing rapidly as a result of this internationalization of higher education. It has seen a sharp increase in entrepreneurship, new ideas, and new institutions of all sorts, as Saudi students return to their home country. Workforce localization is slowly taking place and Saudi citizens are on track to gradually replace the expatriate professional labor force. However, much depends on the continuation of the scholarship program in the years to come. With the passing of King Abdullah and the merger of the ministries of education and higher education by King Salman, it remains to be seen whether the program will continue in its current form, or be subsumed into new priorities and ultimately new realities for the Kingdom of Saudi Arabia.

\section{Past, Present, and Future of Higher Education Interna- tionalization in Russia}

\section{Anna Chamchiyan}

Anna Chamchiyan is a PhD candidate and works as the head of the Department for Academic Mobility and International Programs at Ulyanovsk State Technical University, Russia.E-mail: a.chamchiyan@ gmail.com.

$\mathrm{M}$ odern research works in the field of the Russian higher education development and internationalization are full of contradictions. According to the Organisation for Economic Co-operation and Development, Russia takes second place in the world in the absolute number of higher education students and is one of four top countries (along with the United States of America, India, and China) hosting more than 40 percent of the worldwide higher education student body. But providing a comprehensive evaluation of processes taking place in the Russian higher education system, particularly of the internationalization of Russian higher education, is difficult due to a lack of adequate resources and a manifest disagreement between ambitions and facilities of the Russian higher education system and the actual level of its higher education internationalization and competitiveness.

In the 2oth century, Russian higher education (or Soviet higher education during the period of the Soviet Union) was considered to be one of the strongest academic structures in the world. Now Russia's leading universities are not even listed in the top roo of the world's best universities, although some universities have maintained recognition of excellence in some specific fields of study, such as physics and mathematics. To understand the nature of changes taking place in Russian higher education in the context of general globalization and higher education internationalization, we should take a look at the genesis and the history of the internationalization of higher education in Russia. 